This item was submitted to Loughborough's Research Repository by the author.

Items in Figshare are protected by copyright, with all rights reserved, unless otherwise indicated.

\title{
Geopolitical risks and recessions in a panel of advanced economies: evidence from over a century of data
}

PLEASE CITE THE PUBLISHED VERSION

https://doi.org/10.1080/13504851.2018.1558332

\section{PUBLISHER}

(C) Taylor \& Francis (Routledge)

\section{VERSION}

AM (Accepted Manuscript)

\section{PUBLISHER STATEMENT}

This is an Accepted Manuscript of an article published by Taylor \& Francis in Applied Economics Letters on 15 December 2018, available online: http://www.tandfonline.com/10.1080/13504851.2018.1558332.

\section{LICENCE}

CC BY-NC-ND 4.0

\section{REPOSITORY RECORD}

Clance, Matthew W., Rangan Gupta, and Mark Wohar. 2018. "Geopolitical Risks and Recessions in a Panel of Advanced Economies: Evidence from over a Century of Data”. figshare. https://hdl.handle.net/2134/37191. 


\section{Geopolitical Risks and Recessions in a Panel of Advanced Economies: Evidence from Over a Century of Data}

\section{Introduction}

Geopolitical risks (GPRs) are widely viewed as one of the key determinants of investment decisions, to the extent that, the European Central Bank (2017), in its (April) Economic Bulletin, and the International Monetary Fund (2017), in the (October) World Economic Outlook, highlights geopolitical uncertainties as a salient risk to the economic outlook. However, there is no systematic empirical analysis of the importance of GPRs in predicting macroeconomic cycles. The main reason behind this has to be put down to the lack of a time-consistent measure of GPRs as perceived by the press, the public, global investors, and policy-makers. To address this issue, Caldara and Iacoviello (2018) develop alternative measures of GPRs based on a tally of articles covering issues related with geopolitical tensions published in major international newspapers. Then, inter alia, using these GPR indices on a monthly data set covering the period of 1985 to 2016, these authors, based on a Bayesian Vector Autoregressive (VAR) model, show that GPRs negatively impacts world economic activity, and in particular those of advanced economies.

Against this backdrop, the objective of our paper is to analyze the role played by GPRs (after controlling for other leading indicators) in predicting the recessions of a panel of seventeen advanced economies over the annual period of 1899-2013, using a conditional logit model. To the best of our knowledge, this is the first attempt to use GPRs in trying to explain historical recessions covering over a century of data for advanced economies. The rest of the paper is organized as follows: Section 2 discusses the model and the dataset, while Section 3 presents the results, with Section 4 concluding the paper.

\section{Model and Data}

We estimate a conditional logit model on an unbalanced panel controlling for country fixed effects ${ }^{1}$ :

\footnotetext{
${ }^{1}$ Results based on a conditional probit model yield qualitatively similar results, which, in turn, are available upon request from the authors.
} 


$$
\operatorname{Pr}\left(Y_{i, t}=1 \mid X_{i,(\mathrm{t}-1)}+G P R_{(\mathrm{t}-1)}\right)=\Lambda\left(X_{i,(\mathrm{t}-1)} \beta+\gamma G P R_{(\mathrm{t}-1)}\right)
$$

where, where $Y$ is an indicator (i.e., takes a value 1 ) if a recession occurs in country $i, X$ is a vector of control variables, GPR is an index of the lag of geopolitical risks, and $\Lambda(\cdot)$ is the cumulative distribution of the logistic function. We also disaggregate the GPR index into geopolitical threats, GPRT, and geopolitical acts, GPRA (discussed below in detail). The vector of lagged control variables include the recession dummy (DEPENDENT), and standard predictors used in the recession literature (based on data availability), namely, investment to GDP ratio (INVGDP), consumer price index (CPI) inflation (INFLATION), current account to GDP ratio (CAGDP), openness (OPENNESS defined as (exports+imports)/GDP), narrow money growth $(N M G)$, broad money growth $(B M G)$, short-term interest rates $(S T I R)$, long term interest rates $(L T I R)$, real stock returns $(R S R)$, real house returns $(R H R)$, budget-deficit to GDP $(B D G D P)$, total loans to nonfinancial private sector (which includes mortgage loans to households and loans to businesses) to GDP ratio (LNFPSGDP), public debt to GDP ratio $(D E B T G D P)$, real dollar-based exchange rate returns $(R E R)$, real oil returns $(R O R)$ in domestic currency, and a systemic financial crises dummy (FCRISES). Note that nominal variables are converted to their real counterparts by deflating with the CPI. The expression $\operatorname{Pr}(\cdot)$ is the probability that country $i$ is in recession. In general, the data covers the period of 1899 to 2013, with the start date governed by the GPR data, and the end date driven by the data on the other predictors. However, since some of the predictors in $X$ is not available from 1899, we have an unbalanced panel for the seventeen advanced countries (Australia, Belgium, Canada, Denmark, Finland, France, Germany, Italy, Japan, The Netherlands, Norway, Portugal, Spain, Sweden, Switzerland, United Kingdom (UK), United States of America (USA)) ${ }^{2}$ considered.

The main sources of the predictors comprising $X$ are Jordà et al., (2017) and Knoll et al., (2017), ${ }^{3}$ while data on oil prices are obtained from the Global Financial Database. The information on the recession dummy (i.e., country-specific recession dates), is derived from Funke et al., (2016). The monthly data on GPRs, which is converted to annual frequency by averaging over the twelve-

\footnotetext{
2 The starting dates of each country are: 1899 for Australia, 1982 for Belgium, 1934 for Canada, 1899 for Denmark, 1914 for Finland, 1899 for France, 1899 for Germany, 1971 for Italy, 1914 for Japan, 1899 for The Netherlands, 1899 for Norway, 1989 for Portugal, 1972 for Spain, 1899 for Sweden, 1902 for Switzerland, 1900 for UK, and 1899 for USA.

${ }^{3}$ The weblink for the dataset is: http://www.macrohistory.net/data/.
} 
months, is based on the work of Caldara and Iacoviello (2018). ${ }^{4}$ The GPR index reflects automated text-search results of the electronic archives of 3 national newspapers: The Chicago Tribune, The New York Times, and The Washington Post. Caldara and Iacoviello (2018) then calculate the index by counting the number of articles related to geopolitical risk in each newspaper for each month (as a share of the total number of news articles). The index is then normalized to average a value of 100 in the 2000-2009 decade.

The search identifies articles containing references to six groups of words: Group 1 includes words associated with explicit mentions of geopolitical risk, as well as mentions of military-related tensions involving large regions of the world and a U.S. involvement. Group 2 includes words directly related to nuclear tensions. Groups 3 and 4 include mentions related to war threats and terrorist threats, respectively. Finally, Groups 5 and 6 aim at capturing press coverage of actual adverse geopolitical events (as opposed to just risks) which can be reasonably expected to lead to increases in geopolitical uncertainty, such as terrorist acts or the beginning of a war.

Note that, Caldara and Iacoviello (2018) further disentangle the direct effect of adverse global geopolitical events from the effect of pure geopolitical risks by constructing two indexes: The Geopolitical Threats index (GPRT), which only includes words belonging to Search groups 1 to 4, and the Geopolitical Acts index (GPRA) only includes words belonging to Search groups 5 and 6. Given this, we estimate three models, one with only the lagged variables in $X$ as predictors (MODEL1), then predictors in MODEL1 is supplemented with lagged GPR (MODEL2), and in MODEL3, we have the predictors in MODEL1 plus lagged GPRT and GPRA.

\section{Results}

In Table 1, we present the results of our analysis based on the three models estimated, with the positive and negative signs of the variable showing whether it increases or reduces the chances of causing a recession. Note that, we use one lags of the predictors, since the longer lags of the variables were mostly insignificant, and hence, kept our current set of results qualitatively unchanged. In general, the parameters associated with $X$ remain stable in terms of their sign and significance across the three models, with the exception of DEBTGDP and ROR, which becomes

\footnotetext{
${ }^{4}$ The data is available for download from: https://www2.bc.edu/matteo-iacoviello/gpr.htm.
} 
significant in MODEL3 (with disaggregated GPRs), which happens to be the best model. These two variables are found to increase the probability of recessions. Other significant predictors that increase the probability of recessions are BMG, STIR, RHR and LNFPSGDP, while NMG and LTIR reduce the chances of recessions in the next period.

When we turn to the main focus of the paper, i.e., the role of GPRs in predicting recessions, we find that in MODEL2, where GPR is used, though the fit is slightly better than MODEL1 which excludes $G P R$, the effect is not statistically significant. However, when we turn to the best fitted model, i.e., MODEL3, which uses the disaggregated GPRs in the form of GPRA and GPRT, the coefficient on both these variables are statistically significant. The opposite signs (negative of $G P R T$ and positive on GPRA) on these two variables, possibly explains the insignificant effect of aggregate GPR in MODEL2. While it is understandable that actual geopolitical acts (GPRA) will enhance the chances of recession in the next period, the fact that GPRT reduces the same seems a bit counter-intuitive. But if we look closely as to what comprises this index, which is essentially various forms of possibilities (i.e., threats) of geopolitical risks, one could argue that the government raises defense spending to guard against the actual materialization of such threats, and this spending being growth enhancing (Aye et al., 2014), reduces the chances of probability. ${ }^{5}$

${ }^{5}$ Of course, this line of reasoning remains to be verified, which unfortunately, at this stage, is not feasible given the lack of data on defense spending over our sample period of more than a century, and hence, remains a speculation. 
Table 1. Predicting the Probability of Recessions: $\operatorname{Pr}\left(Y_{i t}=1\right)$

\begin{tabular}{|c|c|c|c|}
\hline$D E P E N D E N T_{t-1}$ & $\begin{array}{c}\text { MODEL1 } \\
-17.101 \\
(719.588)\end{array}$ & $\begin{array}{c}\text { MODEL2 } \\
-17.353 \\
(813.796)\end{array}$ & $\begin{array}{c}\text { MODEL3 } \\
-15.998 \\
(410.814)\end{array}$ \\
\hline$G P R_{t-1}$ & & $\begin{array}{l}-0.073 \\
(0.167)\end{array}$ & \\
\hline$G P R T_{t-1}$ & & & $\begin{array}{c}-0.500^{* * *} \\
(0.158)\end{array}$ \\
\hline$G P R A_{t-1}$ & & & $\begin{array}{c}0.519^{* * *} \\
(0.163)\end{array}$ \\
\hline$I N V G D P_{t-1}$ & $\begin{array}{l}-3.047 \\
(1.966)\end{array}$ & $\begin{array}{c}-2.975 \\
(1.971)\end{array}$ & $\begin{array}{c}1.857 \\
(2.336)\end{array}$ \\
\hline INFLATION $_{t-1}$ & $\begin{array}{c}2.794 \\
(1.948)\end{array}$ & $\begin{array}{c}2.934 \\
(1.966)\end{array}$ & $\begin{array}{l}2.447 \\
(2.004)\end{array}$ \\
\hline$C A G D P_{t-1}$ & $\begin{array}{l}-3.216 \\
(2.428)\end{array}$ & $\begin{array}{l}-3.084 \\
(2.454)\end{array}$ & $\begin{array}{l}-1.868 \\
(2.438)\end{array}$ \\
\hline OPENNESS $_{t-1}$ & $\begin{array}{c}0.364 \\
(0.354)\end{array}$ & $\begin{array}{c}0.358 \\
(0.354)\end{array}$ & $\begin{array}{c}0.238 \\
(0.354)\end{array}$ \\
\hline$N M G_{t-1}$ & $\begin{array}{l}-2.473^{*} \\
(1.441)\end{array}$ & $\begin{array}{l}-2.452^{*} \\
(1.446)\end{array}$ & $\begin{array}{l}-2.722^{*} \\
(1.468)\end{array}$ \\
\hline$B M G_{t-1}$ & $\begin{array}{l}3.593^{* *} \\
(1.820)\end{array}$ & $\begin{array}{l}3.707^{* *} \\
(1.837)\end{array}$ & $\begin{array}{l}3.548^{*} \\
(1.884)\end{array}$ \\
\hline$S T I R_{t-1}$ & $\begin{array}{c}0.203^{* * *} \\
(0.063)\end{array}$ & $\begin{array}{c}0.199^{* * *} \\
(0.064)\end{array}$ & $\begin{array}{l}0.148^{* *} \\
(0.065)\end{array}$ \\
\hline$L T I R_{t-1}$ & $\begin{array}{c}-0.312^{* * *} \\
(0.074)\end{array}$ & $\begin{array}{c}-0.308^{* * *} \\
(0.075)\end{array}$ & $\begin{array}{c}-0.220^{* * *} \\
(0.078)\end{array}$ \\
\hline$R S R_{t-1}$ & $\begin{array}{c}-0.342 \\
(0.485)\end{array}$ & $\begin{array}{l}-0.370 \\
(0.490)\end{array}$ & $\begin{array}{l}-0.265 \\
(0.498)\end{array}$ \\
\hline$R H R_{t-1}$ & $\begin{array}{c}3.181^{* * *} \\
(0.967)\end{array}$ & $\begin{array}{c}3.218^{* * *} \\
(0.972)\end{array}$ & $\begin{array}{c}3.257^{* * *} \\
(0.962)\end{array}$ \\
\hline$B D G D P_{t-1}$ & -0.902 & -1.125 & -0.844 \\
\hline
\end{tabular}




\begin{tabular}{|c|c|c|c|}
\hline$L N F P S G D P_{t-1}$ & $\begin{array}{l}0.753^{* *} \\
(0.359)\end{array}$ & $\begin{array}{l}0.803^{* *} \\
(0.377)\end{array}$ & $\begin{array}{c}1.133^{* * *} \\
(0.400)\end{array}$ \\
\hline$D E B T G D P_{t-1}$ & $\begin{array}{c}0.438 \\
(0.292)\end{array}$ & $\begin{array}{c}0.447 \\
(0.292)\end{array}$ & $\begin{array}{l}0.615^{* *} \\
(0.296)\end{array}$ \\
\hline FCRISES $_{t-1}$ & $\begin{array}{l}-0.870 \\
(0.598)\end{array}$ & $\begin{array}{l}-0.893 \\
(0.601)\end{array}$ & $\begin{array}{l}-0.883 \\
(0.592)\end{array}$ \\
\hline$R E R_{t-1}$ & $\begin{array}{l}-0.218 \\
(0.888)\end{array}$ & $\begin{array}{l}-0.178 \\
(0.893)\end{array}$ & $\begin{array}{c}-0.365 \\
(0.898)\end{array}$ \\
\hline$R_{O R} R_{t-1}$ & $\begin{array}{c}0.523 \\
(0.360)\end{array}$ & $\begin{array}{c}0.506 \\
(0.362)\end{array}$ & $\begin{array}{c}0.721^{*} \\
(0.369)\end{array}$ \\
\hline Fixed Effects & Yes & Yes & Yes \\
\hline AIC & 423.558 & 423.463 & 416.099 \\
\hline BIC & 881.116 & 882.926 & 870.199 \\
\hline Log-Likelihood & 969.637 & 976.654 & 969.134 \\
\hline Pseudo $\mathrm{R}^{2}$ & 0.113 & 0.113 & 0.128 \\
\hline Observations & 1349.000 & 1349.000 & 1349.000 \\
\hline
\end{tabular}

Note: Standard errors in parentheses; ${ }^{*} p<.10,{ }^{* *} p<.05,{ }^{* * *} p<.01$.

In Figure A1 in the Appendix, we present the predicted probability of recessions for the seventeen countries from MODEL 3, superimposed on the actual recession years (as indicated by the black vertical lines). As can be seen, in general, MODEL 3 does quite well in picking up the slow-downs across all the countries, as depicted by the increase in the value of the predicted probability just before the recession in that country.

\section{Conclusions}

In this paper using a panel of seventeen advanced countries over the annual period of 1899-2013, we analyze, for the first time, using a conditional logit model, the role that geopolitical risks might possibly play in predicting recessions in these economies. After controlling for other standard predictors, we find that, while aggregate geopolitical risks does not have any predictive ability, geopolitical acts enhances the probability of future recessions, with geopolitical threats reducing the same. Clearly then, following geopolitical acts, policymakers should be prepared to undertake expansionary policies to drive these economies out of the recession. 


\section{References}

Aye, G.C., Balcilar, M., Dunne, J.P., Gupta, R., and van Eyden, R. (2014). Military expenditure, economic growth and structural instability: a case study of South Africa. Defence and Peace Economics, 25(6), 619-633.

Caldara, D., and Iacoviello, M. (2018). Measuring Geopolitical Risk. Working Paper, Board of Governors of the Federal Reserve Board.

European Central Bank (2017). Economic Bulletin, Issue 4/2017. Available for download at: https://www.ecb.europa.eu/pub/pdf/ecbu/eb201704.en.pdf.

Funke, M., Schularick., and Trebesch, C. (2016). Going to extremes: Politics after financial crises, 1870-2014. European Economic Review, 88, 227-260.

International Monetary Fund (2017). World Economic Outlook: Seeking Sustainable Growth: Short-Term Recovery, Long-Term Challenges, October. Available for download from: https://www.imf.org/en/Publications/WEO/Issues/2017/09/19/world-economic-outlook-october2017.

Jordà, Ò., Schularick, M., and Taylor, A.M. (2017). Macrofinancial History and the New Business Cycle Facts, in NBER Macroeconomics Annual 2016, volume 31, edited by Martin Eichenbaum and Jonathan A. Parker. Chicago: University of Chicago Press, 213-263.

Knoll, K., Schularick, M., and Steger, T. (2017). No Price Like Home: Global House Prices, 18702012. American Economic Review, 107(2), 331-353. 


\section{APPENDIX:}

Figure A1. Plots of Predicting Recession Probability from MODEL 3 with Disaggregated GPRs
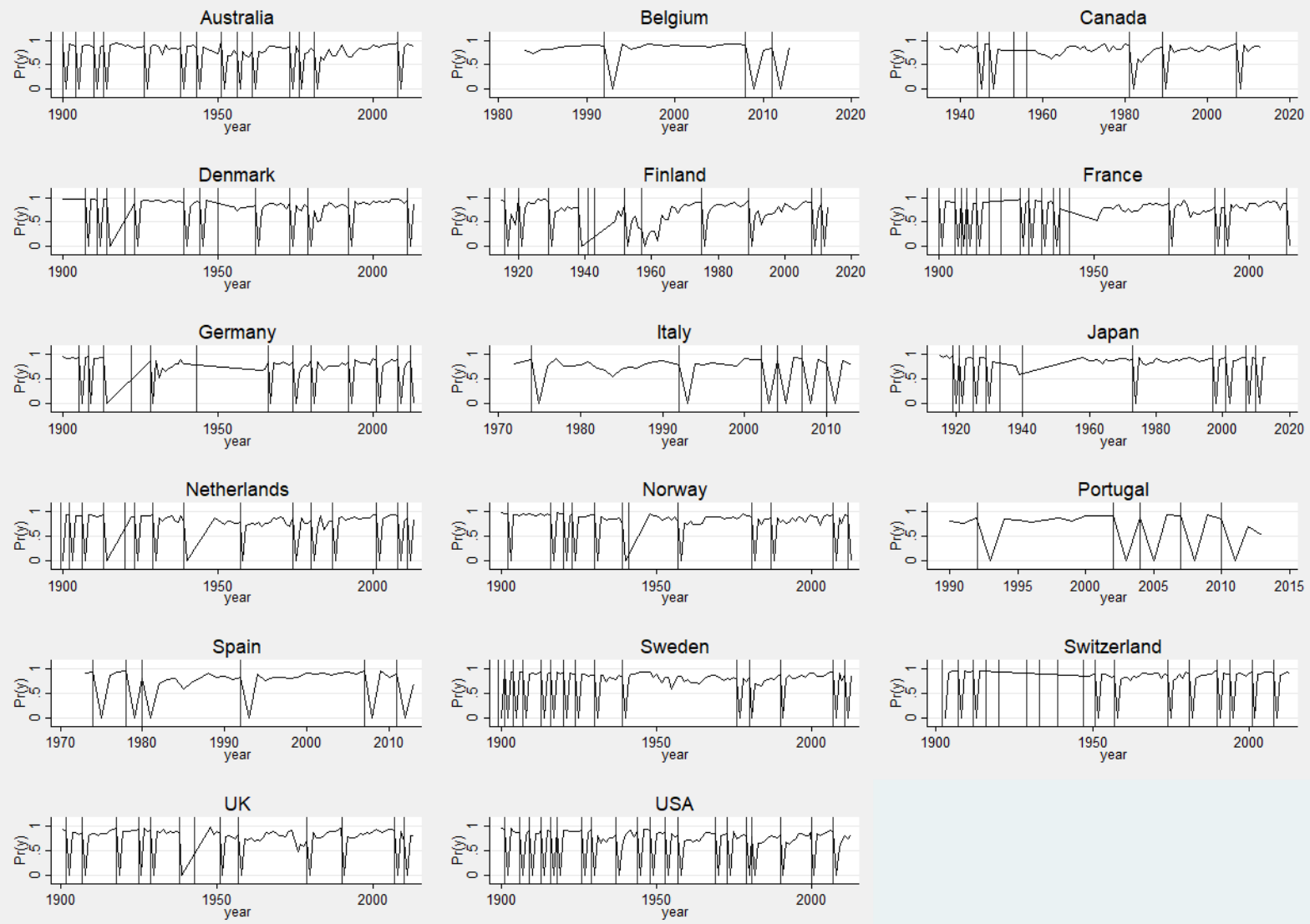

Note: Predicted probabilities $\left(\operatorname{Pr}\left(Y_{i t}=1\right)\right)$ assumes that country fixed effect is equal to zero. 